\title{
Ecophysiology of seed germination in Digitaria insularis ((L.) Fedde $)^{1}$
}

\author{
Ecofisiologia da germinação de sementes de Digitaria insularis ((L.) Fedde)
}

Giovana Soares de Mendonça ${ }^{2}$, Cibele Chalita Martins ${ }^{3 *}$, Dagoberto Martins ${ }^{4}$ e Neumárcio Vilanova da Costa ${ }^{5}$

\begin{abstract}
The invasive behaviour of sourgrass (Digitaria insularis) in cultivated areas is due to its strategy of aggressive regeneration, which is based on seed germination. Knowledge of the physiological ecology of this species can contribute to the development of management and control strategies. The aim of this research was to understand the effects of provenance, temperature and light on the germination of sourgrass seeds collected in the Brazilian state of São Paulo in the cities of Americana, Botucatu and São José do Rio Preto and in the state of Paraná in the city of São Miguel do Iguaçu. The seeds were left to germinate at temperatures of $15,25,35$ and $45^{\circ} \mathrm{C}$, both with and without light. The number of normal seedlings was recorded daily from seven to 60 days. After this period, the seeds together with substrate, were transferred to $25^{\circ} \mathrm{C}$ with light, and a daily count was made for all treatments until the end of germination (75 days after sowing). The seeds of $D$. insularis are positively photoblastic. Seed germination in this species depends on provenance. A temperature of $45{ }^{\circ} \mathrm{C}$ for germination is lethal to the seeds. The temperature of $35{ }^{\circ} \mathrm{C}$ in the presence of light is the most favourable condition for seed germination.
\end{abstract}

Key words: Sourgrass. Plant physiology. Provenance. Light. Temperature.

RESUMO - O comportamento invasivo do capim-amargoso (Digitaria insularis) em áreas de cultivo deve-se à sua estratégia de regeneração agressiva, que está alicerçada na germinação das sementes. O conhecimento da ecofisiologia dessa espécie pode contribuir para o desenvolvimento de estratégias de manejo e controle. Objetivou-se com a presente pesquisa conhecer o efeito de diferentes procedências, temperaturas e luz na germinação de sementes de capim-amargoso. As sementes foram coletadas no Estado de São Paulo nas cidades de Americana, Botucatu e São José do Rio Preto e no Estado do Paraná na cidade de São Miguel do Iguaçu e, colocadas para germinar em temperaturas de $15 ; 25 ; 35$ e $45^{\circ} \mathrm{C}$, com e sem luz. Foram contabilizadas diariamente as plântulas normais de sete a 60 dias. Após esse período, os substratos com sementes foram transferidos para $25^{\circ} \mathrm{C}$ na presença de luz realizando-se contagem diária até que a germinação cessasse em todos os tratamentos (75 dias após a semeadura). As sementes de D. insularis são fotoblásticas positivas. A germinação das sementes desta espécie depende da procedência. A temperatura de $45^{\circ} \mathrm{C}$ para a germinação é letal às sementes. A temperatura de $35^{\circ} \mathrm{C}$ combinada com luz é a condição mais favorável para a germinação das sementes.

Palavras-chave: Capim-amargoso. Fisiologia vegetal. Procedência. Luz. Temperatura.

\footnotetext{
*Autor para correspondência

${ }^{1}$ Recebido para publicação em 03/09/2013; aprovado em 27/06/2014

Parte do trabalho de Graduação da primeira autora e financiamento de bolsa CNPq dos demais autores

${ }^{2}$ Faculdade de Ciências Agrárias e Veterinárias, Universidade Estadual Paulista "Júlio de Mesquita Filho", campus de Jaboticabal, JaboticabalSP, Brasil, giovana.s.m@ hotmail.com

${ }^{3}$ Departamento Produção Vegetal, Faculdade de Ciências Agrárias e Veterinárias, Universidade Estadual Paulista "Júlio de Mesquita Filho", campus de Jaboticabal, Jaboticabal-SP, Brasil, cibele@fcav.unesp.br

${ }^{4}$ Faculdade de Ciências Agronômicas, Universidade Estadual Paulista "Júlio de Mesquita Filho", campus de Botucatu, Botucatu-SP, Brasil, dmartins@fca.unesp.br

${ }^{5}$ Universidade Estadual do Oeste do Paraná/Unioeste, campus de Marechal Cândido Rondon, Marechal Cândido Rondon-PR, Brasil, neumarciovc@hotmail.com
} 


\section{INTRODUCTION}

Digitaria insularis (L.) Fedde, known locally as capim-amargoso, is an important weed species in the cultivation of coffee and citrus crops. Under Brazilian climatic conditions this species occurs in the field throughout the year, and with the confirmation of the existence of glyphosate-resistant biotypes, the problem has worsened (GEMELLI et al., 2012; MELO et al., 2012).

Knowledge of the ecophysiology of seed germination in weeds such as capim-amargoso enables the implementation of studies in the field and in the greenhouse which are aimed at chemical control and the understanding of seed emergence in the soil, besides providing guidelines for the adoption of management practices that are unfavourable to this emergence (GEMELLI et al., 2012; MARTINS; PEREIRA; MARCHI, 2011; MARTINS; MARTINS, 2013).

Germination can be affected by the intrinsic conditions of the seed, such as viability and dormancy, and by environmental factors, such as the temperature and the availability of water, oxygen and light (OAK; NAKAGAWA, 2012).

Light is necessary for the germination of some species of weed, but is not considered a basic factor for nondormant seeds (MARTINS et al., 2000). Seeds are classified according to their response to light as: positively photoblastic, whose ability to germinate increases in the presence of light; negatively photoblastic, which germinate in the absence of light; and neutrally photoblastic, where germination is not affected by light (OAK; NAKAGAWA, 2012).

Various species of Digitaria show different responses to the presence or absence of light for seed germination (KLEIN; FELIPPE, 1991; MONDO et al., 2010). According to Klein and Felippe (1991), seeds of D. horizontalis are positively photoblastic and those of $D$. insularis are neutral.

Although seed germination may take place over wide temperature ranges, there are certain temperatures that enable the maximum speed and uniformity of the process, the so-called optimal temperatures. There are also maximum and minimum temperatures, above and below which no germination occurs (OAK; NAKAGAWA, 2012).

The percentage of germination in D. insularis is relatively high $(50 \%)$ compared to other species of the same genus, such as D. bicornis (Lam.) Roem. and Schult., $D$. ciliaris (Retz.) Koel, and D. horizontalis Willd (MONDO et al., 2010). In these four species a higher percentage and speed of germination were seen under alternating temperatures than under constant temperatures; however that study was conducted with seeds from a single location only, with the requirements of temperature and light being dependent on the species.
The emergence of ecotypes adapted to different conditions of soil and climate is a factor of concern in weed research, as species tend to invade and settle in new areas (BIANCO; BARBOSA JUNIOR; PITELLI, 2004). In the literature there are reports of ecotypes of $D$. insularis with varying growth patterns, aggressiveness and tolerance to herbicides (GEMELLI et al., 2012; MELO et al., 2012).

These ecotypes originate with phenotypic changes that ensure propagation and survival at sites having different conditions of soil, climate and management, thereby contributing to the ecological and evolutionary success of the plant (PITELLI; BIANCO, 2013). The place of origin of the seeds may therefore influence their germination and vigour (BOGNOUNOU et al., 2010; MARTINS et al., 2000).

The aim of this work was to evaluate the effect of different sources, temperature and light on the germination of seeds of $D$. insularis.

\section{MATERIAL AND METHODS}

Seeds of D. insularis were collected in July 2012 in the municipalities of Americana, Botucatu and São José do Rio Preto in the state of São Paulo (SP), and in São Miguel do Iguaçu in the state of Paraná (Figure 1), whose climatic conditions and geographical coordinates are shown in Table 1.

Once harvested, seeds from the four places of origin were taken to the Laboratory of Seed Analysis of the Department of Plant Production at the São Paulo State University (UNESP), Jaboticabal, SP, where they were stored in a dry chamber $\left(45 \% \mathrm{RH}\right.$ and $\left.\pm 20{ }^{\circ} \mathrm{C}\right)$ for approximately one month until the tests were set up.

Figure 1 - The states of São Paulo and Paraná in Brazil, showing the location of the cities of origin of the seeds

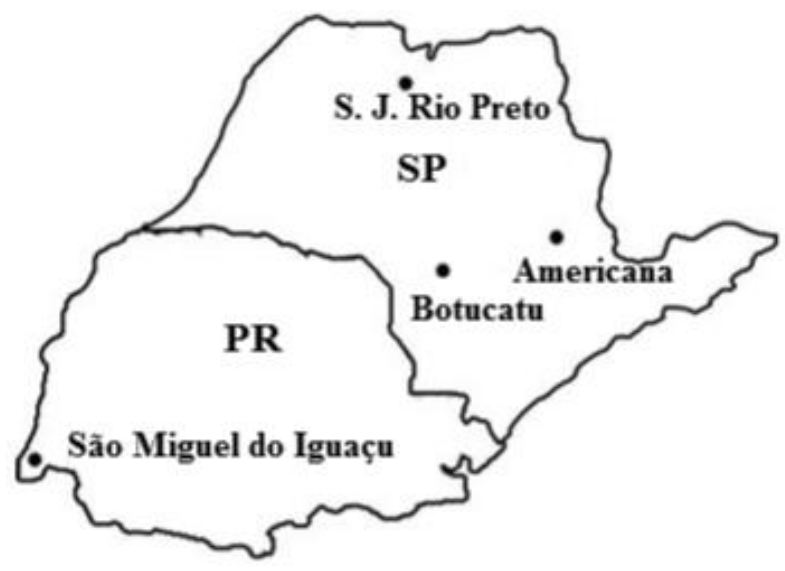


Table 1 - Geographical and climatological information of the origins of the seeds of $D$. insularis used in the trial

\begin{tabular}{|c|c|c|c|c|c|c|c|c|}
\hline \multirow{2}{*}{ Locality** } & \multirow{2}{*}{ Climate* } & \multicolumn{3}{|c|}{ Average annual temperture } & \multirow{2}{*}{ Latitude } & \multirow{2}{*}{ Longitude } & \multirow{2}{*}{ Altitude (m) } & \multirow{2}{*}{ Annual rainfall $(\mathrm{mm})$} \\
\hline & & Mín. & Ave. & Máx. & & & & \\
\hline SJRP & Aw & 17.0 & 23.6 & 30.4 & $20^{\circ} 49^{\prime} 12^{\prime \prime} \mathrm{S}$ & $49^{\circ} 22^{\prime} 44^{\prime \prime}$ W Gr. & 500 & 1,259 \\
\hline BOT & Aw & 15.3 & 20.7 & 26.1 & $22^{\circ} 53^{\prime} 09^{\prime \prime} \mathrm{S}$ & $48^{\circ} 26^{\prime} 42^{\prime \prime} \mathrm{W}$ Gr. & 804 & 1,359 \\
\hline AME & Cwa & 15.3 & 21.8 & 28.2 & $22^{\circ} 44^{\prime} 20^{\prime \prime} \mathrm{S}$ & $47^{\circ} 19^{\prime} 51^{\prime}$ W Gr. & 560 & 1,292 \\
\hline SMI & $\mathrm{Cfa}$ & 16.7 & 21.4 & 27.6 & $25^{\circ} 26^{\prime} 00^{\prime \prime} \mathrm{S}$ & $54^{\circ} 22^{\prime} 00^{\prime \prime} \mathrm{W} \mathrm{Gr}$. & 260 & 1,831 \\
\hline
\end{tabular}

*Köppen climate classificatiopn. Sources: CEPAGRI - Centro de Pesquisas Meteorológicas e Climáticas Aplicadas à Agricultura (2013). IAPAR Instituto Agronômico do Paraná (2013); (**) SJRP (São José do Rio Preto), BOT (Botucatu), AME (Americana) and SMI (São Miguel do Iguaçu)

The germination test was carried out with four replications of 50 seeds, under constant temperatures of $15,25,35$ and $45^{\circ} \mathrm{C}$, on two sheets of germination paper moistened with $12 \mathrm{~mL}$ of distilled water, inside plastic boxes $(11.0 \times 11.0 \times 3.5 \mathrm{~cm})$, both with and without light. For the tests with light, transparent boxes were used at a photoperiod of eight hours; for germination in the dark, black plastic boxes were employed, with the germination counts taken in a dark room under green light.

In evaluating germination, normal germinated seedlings were considered, with a daily count of those with primary root protrusion and well-developed shoots being taken from seven to sixty days after sowing. The first germination count test was performed seven days after sowing. The results were expressed as percentages.

After the period planned for the germination test, the boxes containing seeds that had not germinated were transferred to a chamber set to $25^{\circ} \mathrm{C}$ under light, these being excellent conditions for most cultivated species (MARCOS FILHO, 2005). After transfer, daily counts were taken, again for all treatments, until germination ceased, when the seeds that had germinated where then counted.

The total percentage of viable (live) seeds was calculated at 75 days based on the sum of germinated seeds (germination at the initial temperature plus germination at $25^{\circ} \mathrm{C}$ with light) for the total test period.

The experimental design was completely randomised, in a $4 \times 4 \times 2$ factorial scheme, where the treatments comprised a combination of the four places of origin of the seeds (Americana, Botucatu, São José do Rio Preto and São Miguel do Iguaçu), four germination temperatures $(15,25,35$ and $45^{\circ} \mathrm{C}$ ) and two light conditions (with and without light), with four replications. Whenever the result of the variance analysis was significant at $5 \%$, the averages for the treatments were compared by Tukey test at $5 \%$ probability.

\section{RESULTS AND DISCUSSION}

The summary of the variance analysis for first count and viability showed interactions between origin and temperature, origin and light, and temperature and light. For the parameter germination, a significant effect was seen only from the interaction between temperature and light at $1 \%$ probability (Table 2 ).

In the interaction of origin and temperature (Table 3), an effect was seen for temperature on first germination count for all places of origin. The temperature of $35^{\circ} \mathrm{C}$ was the most favourable, followed by $25^{\circ} \mathrm{C}$. At 15 and $45^{\circ} \mathrm{C}$ there was no germination, independent of origin, as evaluated by the first count test.

As the temperature reduces from the optimal to the minimum, there is a reduction in the rate of germination; this is due to such conditions not favouring the process of imbibition, the enzymatic activity (BHATTACHARJEE; MUKHERJEE, 1995) and consequently, the mobilisation of reserves.

In evaluating the effect of origin, seeds from São José do Rio Preto and Botucatu were superior at a temperature of $25^{\circ} \mathrm{C}$ for rate of germination evaluated by the first count test, compared to those from Americana and San Miguel do Iguacu. At $35^{\circ} \mathrm{C}$, the seeds from Americana in the first count test germinated at a higher percentage than did the others; with the seeds from São José do Rio Preto resulting in the lowest values. Seeds from Botucatu and São Miguel do Iguaçu showed intermediate values when compared to seeds from the other places of origin (Table 3).

From the averages of the interaction between origin and light, it was found that seed germination was stimulated or not by the presence of light depending on the origin, since seeds collected in São José do Rio Preto and Americana expressed higher percentages for germination in the presence of light, while those collected in Botucatu and São Miguel do Iguaçu were not affected; the first germination count of seeds from these towns being similar under both light conditions (Table 4).

Different responses as regards the acceleration of germination in the presence of light may be related to the evolutionary adaptation of the species to the place of origin (BASKIN; BASKIN, 1998; MARTINS et al., 2000; MARTINS et al., 2013). 
Table 2 - Variance analysis of the effect of origin, temperature and light for the tests of first count, germination and viability in seeds of Digitaria insularis

\begin{tabular}{|c|c|c|c|c|}
\hline \multirow{2}{*}{ Cause of variation } & \multirow{2}{*}{ GL } & \multicolumn{3}{|c|}{  } \\
\hline & & First Count & Germination & Viability \\
\hline Origin $(\mathrm{O})$ & 3 & $9.17 * *$ & $17.00 * *$ & $45.75 * *$ \\
\hline Temperature $(\mathrm{T})$ & 3 & $638.40 * *$ & $599.34 * *$ & $709.17 * *$ \\
\hline Light (L) & 1 & $66.42 * *$ & $372.52 * *$ & $74.33 * *$ \\
\hline$(\mathrm{O}) \mathrm{x}(\mathrm{T})$ & 9 & $30.58 * *$ & $3.96^{\mathrm{ns}}$ & $21.42 * *$ \\
\hline$(\mathrm{O}) \times(\mathrm{L})$ & 3 & $13.70 * *$ & $2.18^{\mathrm{ns}}$ & $17.66 * *$ \\
\hline$(\mathrm{T}) \mathrm{x}(\mathrm{L})$ & 3 & $26.05 * *$ & $67.65^{* *}$ & $11.60 * *$ \\
\hline$(\mathrm{O}) \times(\mathrm{T}) \times(\mathrm{L})$ & 9 & $7.67 * *$ & $4.82 * *$ & $20.05^{* *}$ \\
\hline QM (Residual) & 96 & 23.2 & 51.6 & 42.3 \\
\hline C.V $(\%)$ & - & 34.4 & 23.4 & 14.7 \\
\hline
\end{tabular}

**: significant at $1 \%$ probability; ${ }^{\text {ns: }}$ not significant; $\mathrm{MS}=$ mean square

Table 3 - First germination count data $(\%)$ in seeds of $D$. insularis from the breakdown of the interaction between origin and temperature

\begin{tabular}{|c|c|c|c|c|}
\hline \multirow{2}{*}{ Temperature $\left({ }^{\circ} \mathrm{C}\right)$} & \multicolumn{4}{|c|}{--------------------------------------------------Origin-------------------------------------------------- } \\
\hline & São José do Rio Preto & Botucatu & Americana & São Miguel do Iguaçu \\
\hline 15 & $0 \mathrm{aC}$ & $0 \mathrm{aC}$ & $0 \mathrm{aC}$ & $0 \mathrm{aC}$ \\
\hline 25 & $17 \mathrm{aB}$ & $17 \mathrm{aB}$ & $6 \mathrm{bB}$ & $3 \mathrm{bB}$ \\
\hline 35 & $29 \mathrm{cA}$ & $45 \mathrm{bA}$ & $66 \mathrm{aA}$ & $42 \mathrm{bA}$ \\
\hline 45 & $0 \mathrm{aC}$ & $0 \mathrm{aC}$ & $0 \mathrm{aC}$ & $0 \mathrm{aC}$ \\
\hline d.m.s (Origin) & \multicolumn{4}{|c|}{6.3} \\
\hline d.m.s (Temperature) & \multicolumn{4}{|c|}{6.3} \\
\hline
\end{tabular}

Averages followed by the same letter, lowercase on a line and uppercase in a column, do not differ statistically by Tukey test at 5\% probability; m.s.d = minimum significant difference

Table 4 - First germination count data $(\%)$ in seeds of D. insularis from the breakdown of the interaction between light and origin

\begin{tabular}{lcccc}
\hline \multirow{2}{*}{ Light } & Botucatu & Americana & São Miguel do Iguaçu \\
\cline { 2 - 5 } & São José do Rio Preto & $14 \mathrm{bA}$ & $18 \mathrm{abA}$ & $20 \mathrm{aA}$ \\
With & $19 \mathrm{aA}$ & $11 \mathrm{bA}$ & $10 \mathrm{bB}$ & $17 \mathrm{aA}$ \\
Without & $5 \mathrm{cB}$ & \multicolumn{3}{c}{3.4} \\
\hline d.m.s (Origin) & & 4.5 & \\
\hline d.m.s (Light) & & & \\
\hline
\end{tabular}

Averages followed by the same letter, lowercase on a line and uppercase in a column, do not differ statistically by Tukey test at $5 \%$ probability; m.s.d = minimum significant difference

In relation to the effect of the interaction of light and temperature evaluated by the first germination count test (Table 5), it was found for both light conditions, that the temperature of $35{ }^{\circ} \mathrm{C}$ was the most favourable, followed by $25^{\circ} \mathrm{C}$. There was however no difference between the conditions of $25^{\circ} \mathrm{C}$ in the absence of light and the two most unfavourable conditions of 15 and $45^{\circ} \mathrm{C}$. Seeds kept at 15 and $45^{\circ} \mathrm{C}$ did not germinate until the seventh day, when the first count was taken for both light conditions. 
Table 5 - First germination count data (\%) in seeds of $D$. insularis from the breakdown of the interaction between light and temperature

\begin{tabular}{|c|c|c|c|c|}
\hline \multirow{2}{*}{ Light } & \multicolumn{4}{|c|}{ 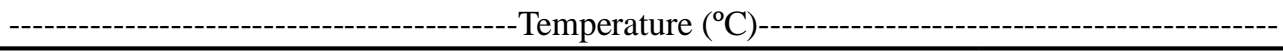 } \\
\hline & 15 & 25 & 35 & 45 \\
\hline With & $0 \mathrm{cA}$ & $20 \mathrm{bA}$ & $50 \mathrm{aA}$ & $0 \mathrm{cA}$ \\
\hline Without & $0 \mathrm{bA}$ & $2 \mathrm{bB}$ & $41 \mathrm{aB}$ & $0 \mathrm{bA}$ \\
\hline d.m.s (Temperature) & \multicolumn{4}{|c|}{3.4} \\
\hline d.m.s (Light) & \multicolumn{4}{|c|}{4.5} \\
\hline
\end{tabular}

In relation to the evaluation of germination for the interaction between temperature and origin, $35{ }^{\circ} \mathrm{C}$ was the most favourable temperature for seed germination, followed by 25 and $15^{\circ} \mathrm{C}$ for all places of origin except São José do Rio Preto (Table 6). The worst temperature was $45{ }^{\circ} \mathrm{C}$ which, with the exception of Americana, precluded germination. These results are similar to those observed in Table 3 for vigour evaluated by first count.

As the temperature rises from optimal to maximum, there is a decrease in oxygen availability and enzyme activity and in the synthesis of RNA, DNA, sugars and ATP (PIROVANO et al., 1997; STEWART et al., 1990), culminating in the coagulation of enzymes and in the deterioration and death of the seeds (SMITH; SHAW; NEWSON, 1992).

At temperatures of 25 and $35^{\circ} \mathrm{C}$, a greater percentage of germination was seen in the seeds from Americana and São José do Rio Preto than in those from Botucatu; these in turn did not differ in germination from those from São Miguel do Iguacu. Overall, at $15{ }^{\circ} \mathrm{C}$, seeds from Botucatu and São José do Rio Preto displayed intermediate values for germination compared to those from Americana and São Miguel do
Iguaçu, which had a higher and lower percentage of germination respectively.

The interaction between origin and light on the germination of the seeds showed that the presence of light was a determining factor in promoting a greater percentage of seed germination for all places of origin. The species therefore produces seeds which are positively photoblastic (Table 7). These results differ from those obtained by Klein and Felippe (1991), who classified the seeds of this species as being indifferent to light. However, those researchers were evaluating seeds from only one area, Piracicaba, SP.

In the presence of light, seeds harvested in both Americana and São José do Rio Preto displayed similar percentages for germination, greater than for the other places of origin where there were no differences in germination. In the absence of light, seeds from the town of Americana displayed the highest values for germination, higher than those from Botucatu or São Miguel do Iguaçu (Table 7). The seeds from São José do Rio Preto displayed intermediate results for germination values, and did not differ from the other places of origin.

Among the temperatures that were evaluated, $35{ }^{\circ} \mathrm{C}$ was the most favourable to germination under

Table 6 - Germination data $(\%)$ in seeds of $D$. insularis from the breakdown of the interaction between origin and temperature

\begin{tabular}{|c|c|c|c|c|}
\hline \multirow{2}{*}{ Temperature $\left({ }^{\circ} \mathrm{C}\right)$} & \multicolumn{4}{|c|}{ 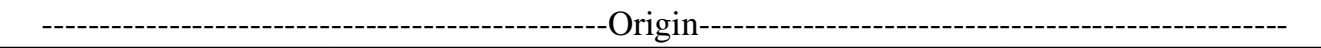 } \\
\hline & São José do Rio Preto & Botucatu & Americana & São Miguel do Iguaçu \\
\hline 15 & $21 \mathrm{abC}$ & $20 \mathrm{abB}$ & $29 \mathrm{aB}$ & $19 \mathrm{bB}$ \\
\hline 25 & $33 \mathrm{aB}$ & $16 \mathrm{cB}$ & $29 \mathrm{abB}$ & $24 \mathrm{bcB}$ \\
\hline 35 & $82 \mathrm{aA}$ & $71 \mathrm{bA}$ & $83 \mathrm{aA}$ & $62 \mathrm{bA}$ \\
\hline 45 & $0 \mathrm{aD}$ & $0 \mathrm{aC}$ & $4 \mathrm{aC}$ & $0 \mathrm{aC}$ \\
\hline d.m.s (Origin) & \multicolumn{4}{|c|}{9.4} \\
\hline d.m.s (Temperature) & \multicolumn{4}{|c|}{9.4} \\
\hline
\end{tabular}

Averages followed by the same letter, lowercase on a line and uppercase in a column, do not differ statistically by Tukey test at 5\% probability; m.s.d $=$ minimum significant difference 
Table 7 - Germination data (\%) in seeds of D. insularis from the breakdown of the interaction between light and origin

\begin{tabular}{|c|c|c|c|c|}
\hline \multirow{2}{*}{ Light } & \multicolumn{4}{|c|}{  } \\
\hline & São José do Rio Preto & Botucatu & Americana & São Miguel do Iguaçu \\
\hline With & $50 \mathrm{aA}$ & $37 \mathrm{bA}$ & $48 \mathrm{aA}$ & $38 \mathrm{bA}$ \\
\hline Without & $19 \mathrm{abB}$ & $16 \mathrm{bB}$ & $25 \mathrm{aB}$ & $15 \mathrm{bB}$ \\
\hline d.m.s (Origin) & \multicolumn{4}{|c|}{6.6} \\
\hline d.m.s (Light) & \multicolumn{4}{|c|}{5.0} \\
\hline
\end{tabular}

both light conditions. The temperatures of 15 and $25{ }^{\circ} \mathrm{C}$ displayed intermediate behaviour and were similar to each other, although without light, the temperature of $45{ }^{\circ} \mathrm{C}$ showed no difference to either (Table 8). The temperature of $45{ }^{\circ} \mathrm{C}$ did not result in seed germination.

As for the interaction between temperature and origin on viability, it was found that the towns of Americana and Botucatu produced seeds that displayed higher viability at $15{ }^{\circ} \mathrm{C}$ than those from São Miguel do Iguaçu and São José do Rio Preto (Table 9).
The superior performance of Americana and Botucatu can be attributed to the dormancy induced by the extreme temperatures which are unfavourable to the species, and could perhaps be a defence mechanism which is able to keep the seeds viable when exposed to adverse conditions (CARVALHO; NAKAGAWA, 2012; MARTINS et al., 2013). Once transferred to the optimal conditions of $25^{\circ} \mathrm{C}$, these seeds would come out of this state of dormancy (Figure 2) in a similar way to that observed for seeds of the melaleuca, also a weed, which is found on waterlogged land (MARTINS et al., 2013).

Table 8 - Germination data (\%) in seeds of $D$. insularis from the breakdown of the interaction between light and temperature

\begin{tabular}{|c|c|c|c|c|}
\hline \multirow{2}{*}{ Light } & \multicolumn{4}{|c|}{-------------------------------------------------Temperature $\left({ }^{\circ} \mathrm{C}\right)------------------------------------------$} \\
\hline & 15 & 25 & 35 & 45 \\
\hline With & $42 \mathrm{bA}$ & $47 \mathrm{bA}$ & $84 \mathrm{aA}$ & $0 \mathrm{cA}$ \\
\hline Without & $2 \mathrm{bB}$ & $4 \mathrm{bB}$ & $66 \mathrm{aB}$ & $2 \mathrm{bA}$ \\
\hline d.m.s (Temperature) & \multicolumn{4}{|c|}{6.6} \\
\hline d.m.s (Light) & \multicolumn{4}{|c|}{5.0} \\
\hline
\end{tabular}

Averages followed by the same letter, lowercase on a line and uppercase in a column, do not differ statistically by Tukey test at 5\% probability; m.s.d $=$ minimum significant difference

Table 9 - Viability data $(\%)$ in seeds of $D$. insularis from the breakdown of the interaction between origin and temperature

\begin{tabular}{|c|c|c|c|c|}
\hline \multirow{2}{*}{ Temperature $\left({ }^{\circ} \mathrm{C}\right)$} & \multicolumn{4}{|c|}{---------------------------------------------------Origin------------------------------------------------------- } \\
\hline & São José do Rio Preto & Botucatu & Americana & São Miguel do Iguaçu \\
\hline 15 & $53 \mathrm{cB}$ & $92 \mathrm{aA}$ & $94 \mathrm{aA}$ & $65 \mathrm{bA}$ \\
\hline 25 & $60 \mathrm{aB}$ & $60 \mathrm{aC}$ & $56 \mathrm{aC}$ & $58 \mathrm{aB}$ \\
\hline 35 & $84 \mathrm{aA}$ & $71 \mathrm{bB}$ & $83 \mathrm{aB}$ & $62 \mathrm{bA}$ \\
\hline 45 & $0 \mathrm{aC}$ & $0 \mathrm{aD}$ & $0 \mathrm{aD}$ & $0 \mathrm{aC}$ \\
\hline d.m.s (Origin) & \multicolumn{4}{|c|}{9.8} \\
\hline d.m.s (Temperature) & \multicolumn{4}{|c|}{9.8} \\
\hline
\end{tabular}

Averages followed by the same letter, lowercase on a line and uppercase in a column, do not differ statistically by Tukey test at $5 \%$ probability; m.s.d $=$ minimum significant difference 
Figure 2 - Germination (\%) in seeds of capim-amargoso (Digitaria insularis (L.) Fedde) over time, in the presence and absence of light at different temperatures, and after 60 days when they were transferred to conditions of $25^{\circ} \mathrm{C}$ with light

WITH LIGTH
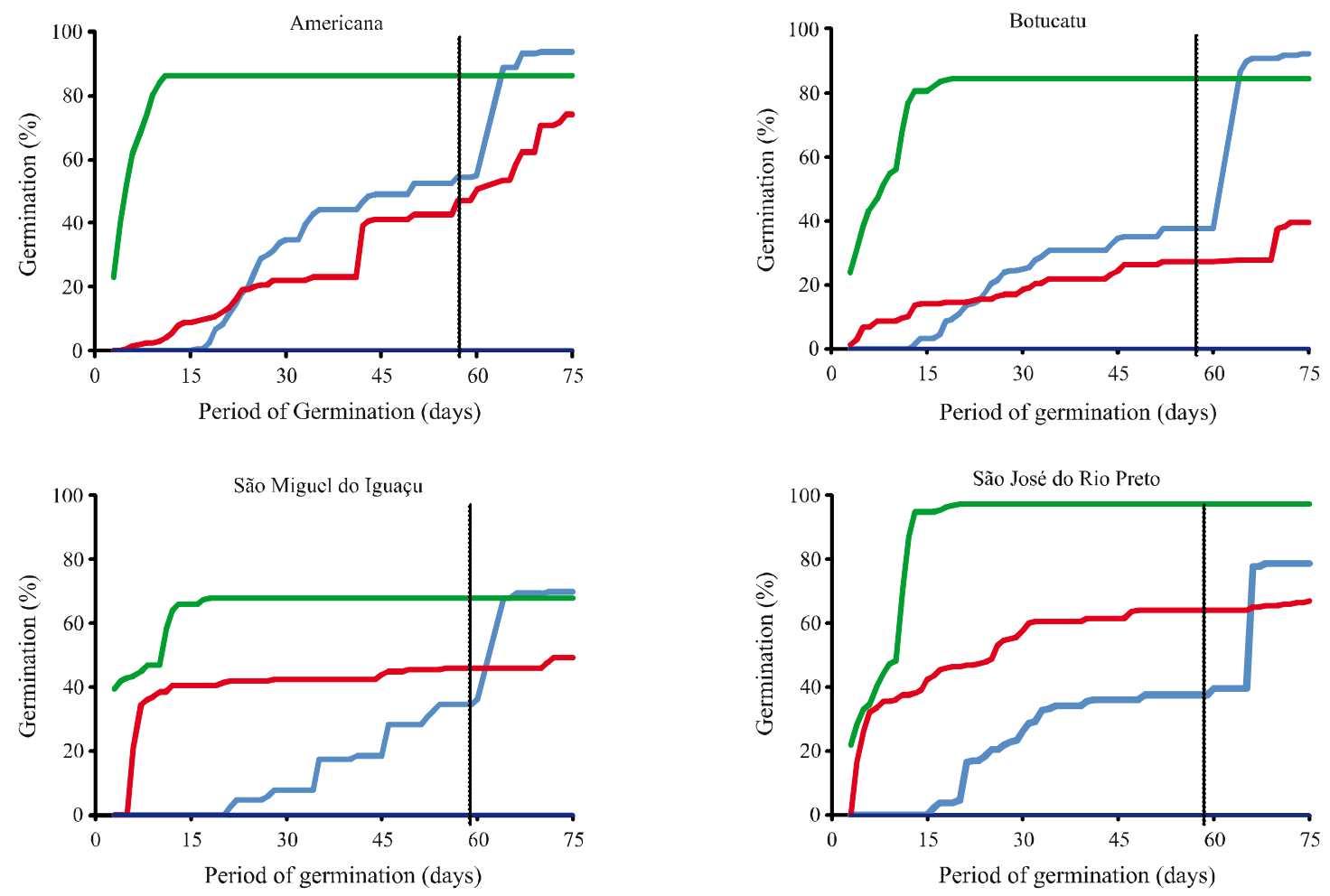

WITHOUT LIGTH


$-15^{\circ} \mathrm{C}-25^{\circ} \mathrm{C} \quad-35^{\circ} \mathrm{C}-45^{\circ} \mathrm{C}$ 
It is also noteworthy that the two sites record minimum annual average temperatures lower than those of São José do Rio Preto and São Miguel do Iguacu (Table 1); climatic conditions may therefore have contributed to the selection of individuals adapted to this environment.

At $25{ }^{\circ} \mathrm{C}$ seeds from the four different places of origin germinated in a similar way to each other (Table 9). At $35{ }^{\circ} \mathrm{C}$ the seeds from São José do Rio Preto and Americana displayed greater viability when compared to the others. Among the places of origin evaluated in this work, it can be noted that these were the towns with the highest annual average and maximum temperatures (Table 1). At these places therefore, the plants must have undergone a selection process for the adaptation and production of seeds that would germinate and remain viable at high temperatures (OLIVEIRA et al., 2014). At $45^{\circ} \mathrm{C}$ germination was not observed for seeds from any of the places of origin (Table 9).

In the interaction between origin and light on seed viability, the presence of light favoured viability in the seeds from Americana, showing higher values similar to those seen in seeds from São José do Rio Preto. However, the seeds from São José do Rio Preto did not differ from those from Botucatu. In the seeds from São Miguel do Iguaçu, lower viability was seen under both light conditions (Table 10). In the absence of light, the seeds from Americana and Botucatu behaved in a similar and superior way to those from the other places of origin.

As regards the interaction between temperature and light on the viability of seeds of capim-amargoso, it was found that for both light conditions the temperature of $45{ }^{\circ} \mathrm{C}$ was lethal to the seeds in a similar way to that observed for seeds of other species of weed, such as leiteiro and melaleuca (MARTINS et al., 2000; MARTINS et al., 2013). High temperatures may therefore have detrimental effects on the germination of seeds (OLIVEIRA et al., 2014). The temperature of $25{ }^{\circ} \mathrm{C}$ resulted in intermediate values for seed viability under both light conditions (Table 11).

For the remaining temperatures, viability in the germination test benefitted from the presence of light. The temperatures of 15 and $35{ }^{\circ} \mathrm{C}$ were the most favourable to viability, with similar results.

Under both light conditions and for all places of origin, the temperature of $35{ }^{\circ} \mathrm{C}$ resulted in maximum germination before 15 days (Figure 2). Therefore, $35{ }^{\circ} \mathrm{C}$ can be considered the optimum temperature for the species (CARVALHO; NAKAGAWA, 2012; MARTINS et al., 2000; MARTINS et al., 2013).

The temperatures of 15 and $25^{\circ} \mathrm{C}$ in the presence of light, made a gradual and progressive germination

Table 10 - Viability data $(\%)$ in seeds of $D$. insularis from the breakdown of the interaction between light and origin

\begin{tabular}{lcccc}
\hline \multirow{2}{*}{ Light } & Botucatu & Americana & São Miguel do Iguaçu \\
\cline { 2 - 5 } & São José do Rio Preto & $54 \mathrm{bA}$ & $64 \mathrm{aA}$ & $47 \mathrm{cA}$ \\
\hline With & $61 \mathrm{aA}$ & $57 \mathrm{aA}$ & $55 \mathrm{aB}$ & $31 \mathrm{cB}$ \\
Without & $38 \mathrm{bB}$ & \multicolumn{3}{c}{5.2} \\
\hline d.m.s (Origin) & & 6.9 & \\
\hline d.m.s (Light) & & & \\
\hline
\end{tabular}

Averages followed by the same letter, lowercase on a line and uppercase in a column, do not differ statistically by Tukey test at $5 \%$ probability; m.s.d = minimum significant difference

Table 11 - Viability $(\%)$ in seeds of $D$. insularis from the breakdown of the interaction between light and temperature

\begin{tabular}{|c|c|c|c|c|}
\hline \multirow{2}{*}{ Light } & \multicolumn{4}{|c|}{ 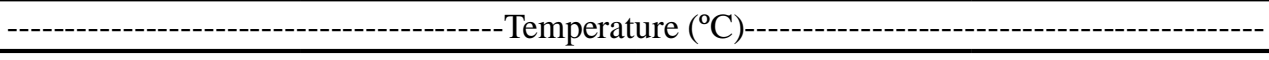 } \\
\hline & 15 & 25 & 35 & 45 \\
\hline With & $84 \mathrm{aA}$ & $58 \mathrm{bA}$ & $84 \mathrm{aA}$ & $0 \mathrm{cA}$ \\
\hline Without & $68 \mathrm{aB}$ & $44 \mathrm{bB}$ & $66 \mathrm{aB}$ & $0 \mathrm{cA}$ \\
\hline d.m.s (Temperature) & \multicolumn{4}{|c|}{6.9} \\
\hline d.m.s (Light) & \multicolumn{4}{|c|}{5.2} \\
\hline
\end{tabular}

m.s.d = minimum significant difference 
of the seeds possible over time. However, with the tests transferred to the condition of $25^{\circ} \mathrm{C}$ with light at 60 days, only those seeds which had been kept at $15^{\circ} \mathrm{C}$ showed a significant increase in germination, reaching values which were similar to or higher than those for the optimum temperature of $35{ }^{\circ} \mathrm{C}$ for Americana, Botucatu and São Miguel do Iguaçu (Figure 2).

Under the condition without light, the temperatures of 15 and $25{ }^{\circ} \mathrm{C}$ displayed a germination of less than $5 \%$ (Figure 2 and Table 8 ), indicating that at temperatures which are different to the optimal, germination is inhibited. Only after the transfer of the tests at 60 days to the conditions of $25^{\circ} \mathrm{C}$ with light, did the seeds display a significant increase in germination. After this transfer, the seeds which had been subjected to a temperature of $15{ }^{\circ} \mathrm{C}$ germinated at a higher or similar percentage to that obtained at the optimal temperature, except those from São José do Rio Preto. The seeds that were initially at $25^{\circ} \mathrm{C}$ in the absence of light also displayed an increase in germination when transferred to $25^{\circ} \mathrm{C}$ with light; however, less evident than that observed for the other evaluated temperatures for most of the places of origin.

It can therefore be said that in general the germinative behaviour of seeds varies according to their place of origin. These results agree with reports in the literature on the existence of ecotypes and differences in germinative behaviour between weed populations (BASKIN, BASKIN, 1998; MELO, 2012).

It can be inferred that the temperatures of 15 and $25{ }^{\circ} \mathrm{C}$ in the presence of light made a gradual and progressive germination of $D$. insularis possible over time, however with the tests being transferred at 60 days to the conditions of $25{ }^{\circ} \mathrm{C}$ with light, only seeds that had been at $15{ }^{\circ} \mathrm{C}$ displayed greater germination, both in the presence and absence of light, except for seeds from São José do Rio Preto. The temperature of $35{ }^{\circ} \mathrm{C}$ can be considered the optimum temperature for the species, while the temperature of $45^{\circ} \mathrm{C}$ was lethal.

\section{CONCLUSIONS}

1. Seed germination in $D$. insularis depends on origin;

2. The seeds of this species are positively photoblastic;

3. A temperature of $45^{\circ} \mathrm{C}$ for germination is lethal to the seeds;

4. A temperature of $35^{\circ} \mathrm{C}$ combined with light is the most favourable condition for seed germination.

\section{REFERENCES}

BASKIN, C. C.; BASKIN, J. M. Causes of within - species variations germination. In: BASKIN, C. C. Seeds: ecology, biogeography, and evolution of dormancy and germination. San Diego: Academic Press, 1998. p. 181-237.

BHATTACHARJEE, S.; MUKHERJEE, A. K. Chillinginduced physiological and biochemical responses in a tropical leaf crop, Amaranthus lividus Linn. Indian Journal of Experimental Biology, v. 33, n. 7, p. 529-532, 1995.

BIANCO, S.; BARBOSA JUNIOR, A. F.; PITELLI, R. A. Crescimento e nutrição mineral de capim-camalote. Planta Daninha, v. 22, n. 3, p. 375-380, 2004.

BOGNOUNOU, F. et al. Seed provenance and latitudinal gradient effects on seed germination capacity and seedling establishment of five indigenous species in Burkina Faso. Tropical Ecology, v. 51, n. 2, p. 207-220, 2010.

BRASIL. Ministério da Agricultura, Pecuáriae Abastecimento. Regras para análise de sementes. Secretaria de Defesa Agropecuária. Brasília: MAPA/ACS, 2009. 395 p.

CARVAlho, N. M.; NAKAGAWA, J. Sementes: ciência, tecnologia e produção. 5. ed. Jaboticabal: FUNEP, 2012. $590 \mathrm{p}$

GEMELLI, A. et al. Aspectos da biologia de Digitaria insularis resistente ao glyphosate e implicações para o seu controle. Revista Brasileira de Herbicidas, v. 11, n. 2, p. 231-240, 2012.

KLEIN, A.; FELIPPE, G.M. Efeito da luz na germinação de sementes de ervas invasoras. Pesquisa Agropecuária Brasileira, v. 26, n. 7, p. 955-966, 1991.

MARCOS FILHO, J. Fisiologia de sementes de plantas cultivadas. Piracicaba: FEALQ, 2005. 495 p.

MARTINS, C.C. et al. Comportamento germinativo de sementes de leiteiro (Peschiera fuchsiaefolia): efeito da temperatura e luz. Planta Daninha, v. 18, n. 1, p. 85-91, 2000.

MARTINS, C. C. et al. Eco-physiological aspects of melaleuca seeds germination. International Journal of Food, Agriculture and Environment, v. 11, p. 1157-1161, 2013.

MARTINS, C. C.; MARTINS, D. Superação da dormência de sementes de gramíneas. In: SILVA, J. F.; MARTINS, D. (Ed.). Manual de aulas práticas de plantas daninhas. Jaboticabal: Funep, 2013. cap. 8, p. 45-56.

MARTINS, C. C.; PEREIRA, M. R. R.; MARCHI, S. R. Germinação de sementes de Melaleuca quinquenervia em condições de estresse hídrico e salino. Planta Daninha, v. 29, n. 1, p. 1-6, 2011.

MELO, M. S. C. et al. Alternativas para o controle químico de capim-amargoso (Digitaria insularis) resistente ao glyphosate. Revista Brasileira de Herbicidas, v. 11, n. 2, p. 195-203, 2012.

MONDO, V. H. V. et al. Efeitos da luz e temperatura na germinação de sementes de quatro espécies de plantas daninhas do gênero Digitaria. Revista Brasileira de Sementes, v. 32, n. 1, p. 131-137, 2010. 
OLIVEIRA, S. S. C. et al. Seleção de progênies de naboforrageiro para germinação sob altas temperaturas. Ciência Rural, v. 44, n. 2, p. 217-222, 2014.

PIROVANO, L. et al. Differences in the reactivation process in thermosensitive seeds of Phacelia tanacetifolia with germination inhibited by high temperature. Physiologia Plantarum, v. 99, n. 2, p. 211-220, 1997.

PITELli, R. A.; BIANCO, S. Avaliações de índices fitossociológicos em comunidades infestantes de agroecossistemas. In: SILVA, J. F.; MARTINS, D. (Ed.).
Manual de aulas práticas de plantas daninhas. Jaboticabal: Funep, 2013. cap. 1, p. 1-8.

SMITH, C. A.; SHAW, D. R.; NEWSON, L. J. Arrow leaf sida (Sida rhombifolia) and prickly sida (Sida spinosa): germination and emergence. Weed Research, v. 32, n. 2, p. 103-109, 1992.

STEWART, C. R. et al. Respiration and alternative oxidase in corn seedling tissues during germination at different temperatures. Plant Physiology, v. 92, n. 3, p. 755 -760, 1990. 